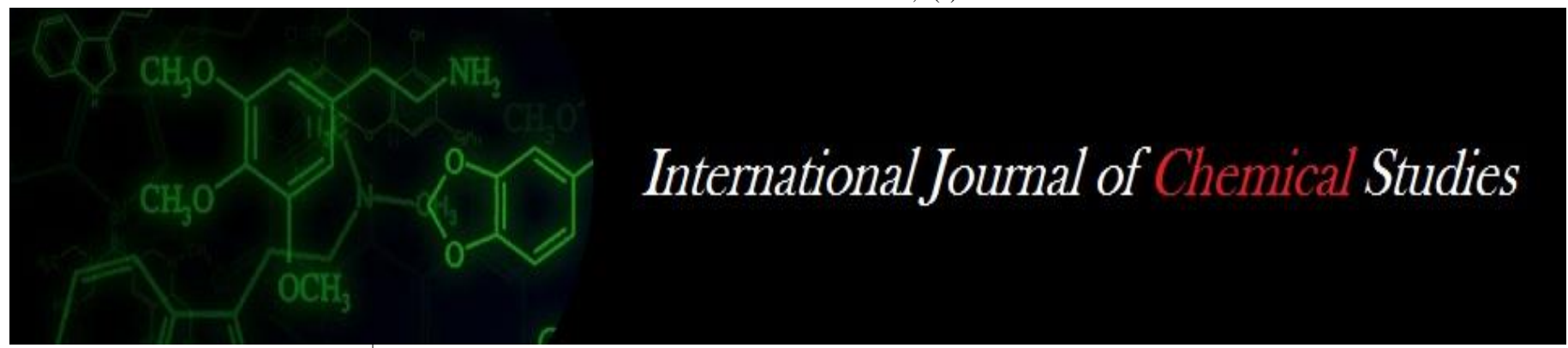

P-ISSN: 2349-8528

E-ISSN: 2321-4902

IJCS 2020; 8(1): 1374-1376

(C) 2020 IJCS

Received: 22-11-2019

Accepted: 24-12-2019

Animesh Sarkar

Department of Soil Science and Agricultural Chemistry, College of Agriculture, Central

Agricultural University, Imphal,

Manipur, India

N Surbala Devi

Department of Soil Science and Agricultural Chemistry, College of Agriculture, Central Agricultural University, Imphal, Manipur, India
Corresponding Author: Animesh Sarkar Department of Soil Science and Agricultural Chemistry, College of Agriculture, Central

Agricultural University, Imphal, Manipur, India

\section{Effect of boron and farmyard manure application on boron concentration and dry matter yield of paddy}

\author{
Animesh Sarkar and N Surbala Devi
}

DOI: https://doi.org/10.22271/chemi.2020.v8.i1s.8446

\section{Abstract}

A pot experiment was conducted to study the effect of boron applied at four levels (viz., 0, 0.5, 1 and $2 \mathrm{~kg}$ $\mathrm{B} \mathrm{ha}^{-1}$ ) and FYM applied at 0 and $5 \mathrm{t} \mathrm{ha}^{-1}$ on boron concentration as well as dry matter yield of paddy (var. CAU-R1) grown in an acid soil. Results revealed that irrespective of different levels of boron and FYM, there was an increasing trend of boron concentration and dry matter yield up to harvest. Significantly higher boron was accumulated in paddy grown in soil added with boron over control at different crop growth stages. Interaction of boron and FYM levels had no significant influence on boron concentration during the whole experiment. Application of boron @ $2 \mathrm{~kg} \mathrm{ha}^{-1}$ and 5 tonnes ha ${ }^{-1} \mathrm{FYM}$ in combination enhanced the boron concentration and dry matter yield at the latter growth stages of paddy. This shows more agronomic effectiveness of boron when applied in combination with FYM.

Keywords: Boron, FYM, boron concentration, dry matter yield, paddy

\section{Introduction}

Micro nutrient plays a key role in quality food grain production. Boron is an essential micronutrient for plants and essentiality of boron was first discovered by K. Warrington in 1923. It is the second most deficient micronutrient in Indian soils after zinc presently (Sathya et al. (2009) ${ }^{[9]}$. Its deficiency is commonly observed in light-textured acidic soils, in soils with high amount of calcium carbonate $\left(\mathrm{CaCO}_{3}\right)$ or oxides and hydrous oxides of iron $(\mathrm{Fe})$ and aluminium $(\mathrm{Al})$, and in soils with low organic-matter content. Its deficiencies are related to high rain fall areas with acidic soil environment. Under acid soil conditions, boron is more water soluble and can therefore be leached below the root-zones of plants by rainfall. The range between deficiency and toxicity is very narrow and hence boron needs judicious fertility management. Boron plays important role in carbohydrate, phenol, auxin metabolism; transport of sugar, cell wall structure and membrane associated reactions, tissue development and differentiation. Boron deficiency in plant inhibits pollen germination and pollen tube growth, nitrogen fixation and also causes. Acute boron deficiency has been reported in the range of 1$69 \%$ (average 33\%) in Indian rice fields (Singh, 2001) ${ }^{[12]}$. Rice (Oryza sativa L.) is one of the most important cereals grown in worldwide. Nearly around 3.5 billion or more worlds' population depends on rice for more than $20 \%$ of their daily energy requirements. In 2017 worldwide rice production was 769.65 million tonnes in which Asia region contributed $90 \%$ of the total rice production. In Asia region rice is the main cereal in terms of productions and consumptions both. China and India are the major rice producing country in the world as well as in the Asia region; they have produced 212.67 million tonnes and 168.50 million tonnes of rice respectively (FAO 2017) ${ }^{[4]}$. Keeping this in view a pot experiment was undertaken to study effect of boron and FYM on boron concentration and dry matter accumulation of paddy.

\section{Materials and Methods}

A pot experiment was conducted in the Department of Soil Science and Agricultural Chemistry, College of Agriculture, Central Agricultural University, Iroisemba, Imphal during the kharif season of 2018 An acidic soil bearing the general characteristics as presented in Table 1 was collected from the research farm of the College of Agriculture, Central Agricultural University, Iroisemba, Imphal by taking multiple thin slices from the surface soil 
layer (0-20 cm depth) as outlined by Jackson $(1973)^{[6]}$. Five $\mathrm{kg}$ each of air dried soil was taken in a series of pots. Recommended dose of nitrogen, phosphorus and potassium were added at $60 \mathrm{~kg} \mathrm{~N} \mathrm{ha}^{-1}, 40 \mathrm{~kg} \mathrm{P}_{2} \mathrm{O}_{5} \mathrm{ha}^{-1}$ and $30 \mathrm{~kg} \mathrm{~K}_{2} \mathrm{O}$ $\mathrm{ha}^{-1}$ in the form of urea, single super phosphate and muriate of potash, respectively to each pot as basal application. Different levels of boron in the form of borax (viz., 0, 0.5, 1 and $2 \mathrm{~kg} \mathrm{~B}$ $\mathrm{ha}^{-1}$ ) in combination with farmyard manure (FYM @ 0 and 5 tonnes $h^{-1}$ ) were mixed thoroughly with the soil according to different set of treatments. FYM was added 15 days before transplanting and boron as basal application. Two twenty five days old seedlings of rice var. CAU R-1 were transplanted in each pot. Each pot was kept in submerged condition throughout the period of experiment maintaining one seedling pot $^{-1}$ and water level at $5-10 \mathrm{~cm}$ above the soil surface.

The experiment was carried out under factorial randomized block design (FRBD). Altogether there were eight treatment combinations replicated thrice.

The whole plants were collected on $25^{\text {th }}, 50^{\text {th }}, 75^{\text {th }}, 100^{\text {th }}$ day after transplanting (DAT) and at harvest by destructive sampling. The collected plant samples were washed properly with tap water and finally rinsed with deionized water. The plant material was then dried at $60{ }^{\circ} \mathrm{C}$ for 48 hours in a hot air oven and dry matter yield was recorded.

The dried plant samples of each treatments were powdered in stainless steel grinder and kept for dry ashing in a muffle furnace at $550{ }^{\circ} \mathrm{C}$ for 5 hours and then ash was extracted in $10 \mathrm{~mL} 0.36 \mathrm{~N} \mathrm{H}_{2} \mathrm{SO}_{4}$ for 1 hour at room temperature as described by Gaines and Mitchell (1979) ${ }^{[5]}$. Plant boron uptake was determined colorimetrically by using azomethine$\mathrm{H}$ method at $420 \mathrm{~nm}$ wavelengths. Soil texture, $\mathrm{pH}$, EC, organic carbon, CEC, available $\mathrm{N}, \mathrm{P}$ and $\mathrm{K}$ were determined following the standard procdures as described by Jackson $(1973)^{[6]}$.

All the data pertaining to the investigation was statistically analysed through analysis of variance technique for comparing the treatments effects. The significance of various effects was tested at $5 \%$ level of probability.

\section{Result and Discussion}

\subsection{Effect of Boron and FYM on boron concentration in} paddy

Data on changes in the amount of boron concentration in paddy grown in soil applied with boron and FYM are presented in Table 2. Results showed that irrespective of different treatments boron concentration showed an increasing trend with crop growth till harvest. Comparing with control, significantly higher boron was accumulated in plants grown in soil added with boron @ $2 \mathrm{~kg} / \mathrm{ha}$ on $25^{\text {th }}, 50^{\text {th }}$ and $75^{\text {th }}$ DAT. This is at par with the findings of Sharma et al. (1999) ${ }^{[10]}$; Mandal and Das (2011) ${ }^{[7]}$. Further study revealed that boron application enhanced its accumulation in plant over control on $100^{\text {th }}$ DAT and at harvest. However, no significant difference was recorded between different boron levels $(0.5 .10$ and $2 \mathrm{~kg}$ B/ ha) at different growth stages. Comparatively higher plant boron content was found in FYM added soil than untreated one on $100^{\text {th }}$ DAT. Critical analysis of the data revealed that the interaction of boron and FYM levels had no significant influence on boron concentration during the whole experiment.

\subsection{Effect of Boron and FYM on dry matter yield of paddy}

Irrespective of different levels of boron and FYM, there was an increasing trend of dry matter yield up to harvest (Table 3). In general, comparatively higher dry matter yield of paddy was observed in soil treated with boron over control on $75^{\text {th }}$ and $100^{\text {th }}$ DAT and at harvest. Similar reports on enhanced dry matter yield due to boron application were given by Chaudhury and Debnath (2006) ${ }^{[2]}$; Ahmed et al. (2011) [1]; Mandal and Das (2011) ${ }^{[7]}$, Padbhushan and Kumar (2015) ${ }^{[8]}$ Sidhu and Kumar (2018) ${ }^{[11]}$. At the earlier growth stages $\left(25^{\text {th }}\right.$ and $50^{\text {th }}$ DAT) effect of boron and FYM was not significant but dry matter production increased over control treatment. Further study revealed that, irrespective of different boron levels, application of FYM @ 5 tons/ha resulted significantly enhanced dry matter yield at the latter stages of crop growth i.e. $75^{\text {th }}$ and $100^{\text {th }}$ DAT and at harvest. Enhanced agronomic effectiveness of boron and FYM was reflected in increased dry matter yield. Plant dry matter yield was increased significantly with the increasing levels of boron at the time of harvest. Comparing among the different boron treatments significantly higher dry matter yield was recorded in soil treated with $2 \mathrm{~kg} \mathrm{ha}^{-1}$ followed by $1 \mathrm{~kg} \mathrm{ha}^{-1}$ and $0.5 \mathrm{~kg} \mathrm{ha}^{-1}$ at harvest. For production of adequate amount of grain yield dry matter production is very important. Fageria and Baligar (1999) ${ }^{[3]}$ reported a positive significant correlation of dry matter production with grain yield of lowland rice from active tillering stage to till physiological maturity.

Table 1: General characteristics of the soil used in the experiment

\begin{tabular}{|c|c|}
\hline Soil Characteristics & Results \\
\hline Textural Class & Textural Class \\
\hline Sand (\%) & 26.2 \\
\hline Silt (\%) & 47.05 \\
\hline Clay (\%) & 26.75 \\
\hline $\mathrm{pH}(1: 2.5$ Soil: water ratio) & 5.11 \\
\hline EC (1:2.5 Soil: water ratio, $\left.\mathrm{dsm}^{-1}\right)$ & 0.23 \\
\hline CEC $\left[\mathrm{cmol}\left(\mathrm{p}^{+}\right) \mathrm{kg}^{-1}\right]$ & 15.4 \\
\hline Organic carbon $(\%)$ & 1.33 \\
\hline Available nitrogen $\left(\mathrm{kg} \mathrm{ha}^{-1}\right)$ & 288.50 \\
\hline Available phosphorus $\left(\mathrm{kg} \mathrm{ha}^{-1}\right)$ & 81.88 \\
\hline Available potassium $\left(\mathrm{kg} \mathrm{ha}^{-1}\right)$ & 216.78 \\
\hline
\end{tabular}


Table 2: Effect of Boron and FYM on boron concentration $\left(\mathrm{mg} \mathrm{kg}^{-1}\right)$ in paddy

\begin{tabular}{|c|c|c|c|c|c|c|c|c|c|c|c|c|c|c|c|}
\hline \multirow{2}{*}{ Treatments } & \multicolumn{3}{|c|}{25 DAT } & \multicolumn{3}{|c|}{ 50 DAT } & \multicolumn{3}{|c|}{75 DAT } & \multicolumn{3}{|c|}{100 DAT } & \multicolumn{3}{|c|}{ At harvest } \\
\hline & $F_{1}$ & $\mathbf{F}_{2}$ & Mean & $F_{1}$ & $\mathbf{F}_{2}$ & Mean & $F_{1}$ & $F_{2}$ & Mean & $F_{1}$ & $\mathbf{F}_{2}$ & Mean & $F_{1}$ & $\mathbf{F}_{2}$ & Mean \\
\hline $\mathrm{B}_{1}$ & 1.43 & 1.22 & 1.32 & 3.48 & 4.88 & 4.18 & 5.02 & 5.58 & 5.30 & 5.69 & 6.61 & 6.15 & 7.35 & 9.31 & 8.33 \\
\hline $\mathrm{B}_{2}$ & 1.86 & 1.57 & 1.71 & 4.60 & 4.89 & 4.74 & 6.80 & 7.89 & 7.34 & 8.57 & 10.77 & 9.67 & 13.97 & 14.05 & 14.01 \\
\hline $\mathrm{B}_{3}$ & 2.66 & 2.51 & 2.58 & 5.33 & 6.07 & 5.70 & 7.65 & 10.69 & 9.17 & 8.68 & 10.84 & 9.76 & 14.58 & 14.83 & 14.71 \\
\hline $\mathrm{B}_{4}$ & 2.88 & 3.07 & 2.98 & 6.57 & 7.19 & 6.88 & 10.52 & 11.01 & 10.77 & 10.34 & 12.68 & 11.51 & 14.68 & 17.61 & 16.15 \\
\hline Mean & 2.21 & 2.09 & & 4.99 & 5.76 & & 7.50 & 8.79 & & 8.32 & 10.23 & & 12.64 & 13.95 & \\
\hline Source & \multicolumn{3}{|c|}{ SE(d) C.D0.05 } & \multicolumn{3}{|c|}{ SE(d) C.D0.05 } & \multicolumn{3}{|c|}{ SE(d) C.D0.05 } & $\mathrm{SE}(\mathrm{d})$ & \multicolumn{2}{|c|}{\begin{tabular}{|r} 
C.D0.05 \\
\end{tabular}} & \multicolumn{2}{|c|}{$\mathrm{SE}(\mathrm{d})$} & C.D0.05 \\
\hline $\mathrm{B}$ & 0.24 & & 0.51 & 0.75 & & 1.62 & 0.96 & & 2.07 & 0.89 & & 1.92 & 2. & & 5.10 \\
\hline $\mathrm{F}$ & 0.17 & & NS & 0.53 & & NS & 0.68 & & NS & 0.63 & & 1.35 & 1. & & NS \\
\hline BXF & 0.34 & & NS & 1.07 & & NS & 1.36 & & NS & 1.26 & & NS & 3. & 36 & NS \\
\hline
\end{tabular}

B1= Boron@ @ kg/ha

B2=Boron@ $0.5 \mathrm{~kg} / \mathrm{ha}$

B3= Boron @ $1 \mathrm{~kg} / \mathrm{ha}$

B4=Boron @ 2 kg/ha
F1=FYM @ 0 tonnes/ha

F2=FYM @ 5 tonnes/ha

$\mathrm{SE}(\mathrm{d})=$ Standard error of mean difference

CD0.05 = Critical difference at $5 \%$ level of probability

NS $=$ Non Significant

Table 3: Effect of Boron and FYM on dry matter yield $\left(\mathrm{g} \mathrm{hill}^{-1}\right)$ of paddy

\begin{tabular}{|c|c|c|c|c|c|c|c|c|c|c|c|c|c|c|c|}
\hline \multirow{2}{*}{ Treatments } & \multicolumn{3}{|c|}{25 DAT } & \multicolumn{3}{|c|}{50 DAT } & \multicolumn{3}{|c|}{75 DAT } & \multicolumn{4}{|c|}{100 DAT } & \multicolumn{2}{|c|}{ At harvest } \\
\hline & $F_{1}$ & $F_{2}$ & Mean & $F_{1}$ & $\mathbf{F}_{2}$ & Mean & $F_{1}$ & $F_{2}$ & Mean & $\mathbf{F}_{1}$ & $F_{2}$ & Mean & $F_{1}$ & $\mathbf{F}_{2}$ & Mean \\
\hline $\mathrm{B}_{1}$ & 3.37 & 3.69 & 3.53 & 5.48 & 6.95 & 6.22 & 11.80 & 12.74 & 12.27 & 15.87 & 18.48 & 17.17 & 18.02 & 21.62 & 19.82 \\
\hline $\mathrm{B}_{2}$ & 3.55 & 3.58 & 3.56 & 7.63 & 7.10 & 7.36 & 13.73 & 14.95 & 14.34 & 18.79 & 26.09 & 22.44 & 24.03 & 25.62 & 24.83 \\
\hline $\mathrm{B}_{3}$ & 3.72 & 3.60 & 3.66 & 6.80 & 7.73 & 7.27 & 13.69 & 16.75 & 15.22 & 18.76 & 25.49 & 22.12 & 25.79 & 29.54 & 27.66 \\
\hline $\mathrm{B}_{4}$ & 3.67 & 3.75 & 3.71 & 7.84 & 8.08 & 7.96 & 16.97 & 19.45 & 18.21 & 24.37 & 25.73 & 25.05 & 29.30 & 33.17 & 31.24 \\
\hline Mean & 3.58 & 3.65 & & 6.94 & 7.47 & & 14.05 & 15.98 & & 19.45 & 23.95 & & 24.29 & 27.49 & \\
\hline Source & \multicolumn{3}{|c|}{ SE(d) C.D0.05 } & \multicolumn{3}{|c|}{ SE(d) C.D0.05 } & \multicolumn{3}{|c|}{ SE(d) C.D0.05 } & \multicolumn{2}{|c|}{\begin{tabular}{l|l}
$\mathrm{SE}(\mathrm{d})$ & \\
\end{tabular}} & C.D0.05 & \multicolumn{2}{|c|}{ SE(d) } & C.D0.05 \\
\hline $\mathrm{B}$ & 0.55 & & NS & 0.92 & & NS & 0.95 & & 2.05 & 1.96 & & 4.21 & 0. & & 2.07 \\
\hline $\mathrm{F}$ & 0.39 & & NS & 0.65 & & NS & 0.67 & & 1.45 & 1.39 & & 2.98 & 0. & & 1.46 \\
\hline BXF & 0.78 & & NS & 1.30 & & NS & 1.35 & & NS & 2.77 & & NS & 1. & 36 & NS \\
\hline
\end{tabular}

B1=Boron@0kg/ha

B2=Boron@0.5 kg/ha

B3=Boron@1 kg/ha

SE $(d)=$ Standard error of mean difference

F1=FYM @ 0 tonnes/h

F2=FYM @ 5 tonnes/ha

CD0.05 = Critical difference at $5 \%$ level of probability

NS $=$ Non Significant

\section{Conclusion}

Significantly higher boron was accumulated in paddy grown in soil applied with boron over control at different paddy growth stages. Application of boron@ $2 \mathrm{~kg} \mathrm{ha}^{-1}$ and 5 tonnes ha $^{-1}$ FYM in combination enhanced the boron concentration and dry matter yield at the latter growth stages. This shows higher agronomic efficiency of combined application of boron and FYM.

\section{References}

1. Ahmed N, Abid M, Ahmad F, Ullah MA, Javaid Q, Ali MA. Impact of boron fertilization on dry matter production and mineral constitution of irrigated cotton. Pakistan Journal of Botany. 2011; 43:2903-2910.

2. Chaudhury SG, Debnath A. Available boron and molybdenum status in some acid soils of West Bengal, Journal of Interacademicia. 2006; 10:171-176.

3. Fageria NK, Baligar VC. Yield and yield components of lowland rice as influenced by timing of nitrogen fertilization. Journl of Plant Nutrition. 1999; 22:23-32.

4. FAO. The state of food and agriculture, climate change, agriculture and food security. FAO, Rome, 2017.

5. Gaines TP, Mitchell GA. Boron determination in plant tissue by the azomethine-H method. Communications in Soil Scince and Plant Analysis. 1979; 10:1099-1108.

6. Jackson ML. Soil Chemical Analysis, Prentice Hall of India Pvt. Ltd. New Delhi, 1973.

7. Mandal M, Kumar Das D. Effect of boron management on the yield of rape (Brassica campestris) and its mobility in soil and plant. Indian Journal of Agricultural Sciences. 2011; 81:1180.
8. Padbhushan R, Kumar D. Soil boron fractions and response of green gram in calcareous soils. Journal of plant nutrition. 2015; 38:1143-1157.

9. Sathya S, Pitchai GJ, Indirani R. Boron nutrition of crops in relation to yield and quality-a review. Agric. Revi. 2009; 30:139-144.

10. Sharma KR, Srivastava PC, Ghosh D, Gangwar MS. Effect of boron and farmyard manure application on growth, yields, and boron nutrition of sunflower. Journal of plant nutrition. 1999; 22:633-640.

11. Sidhu GS, Kumar D. Influence of soil applied boron on yield of berseem (Trifolium alexandrium L.) and soil boron fractions in calcareous soils. Journal of plant nutrition. 2018; 41:980-995.

12. Singh MV. Evaluation of current micronutrient stocks in different agro-ecological zones of India for sustainable crop production. Fertiliser News. 2001; 46:25-42. 